filosofien selv. Bogen slutter med at skitsere nogle figurer over problematikkernes spændingsfelter, der vil kunne benyttes som inspiration til udforskning af videre problemstillinger.

Måske skal Steen Nepper Larsens bog først og fremmest ses som dette sidste, nemlig som inspiration. Om teserne holder stik er ikke det afgørende og heller ikke bogens projekt; den er et slags arbejdspapir, et supplement til en forskningsproces, der både vækker tanken og på fin vis introducerer dette felt. Et felt, der er interessant i sig selv, men som faktisk også kunne fungere som kulisse for en moderne genopsætning af gamle filosofiske klassikere som f.eks. Hvad er ånd?

ANJA SKAAR JACOBSEN

\section{Den sidste kantianer}

Dan Charly Christensen: Naturens tankelaser: En biografi om Hans Christian Ørsted, 2 bd., Museum Tusculanum, 2009, 1209 sider, 498,- kr.

Hans Christian Ørsted (17771851) er en af de største danske naturvidenskabsmænd nogensinde. Besiddende en magtfuld post som ualmindelig initiativrig professor ved universitetet var han allerede verdensberømt i Køben- havn, længe inden han opdagede elektromagnetismen i 1820. Opdagelsen udødeliggjorde med ét slag hans navn i videnskabshistorien. Undertiden møder man den holdning, at elektromagnetismen bare var et fænomen Ørsted tilfældigt faldt over midt under en forelæsning. Derudover er det en udbredt opfattelse, at Ørsted ikke lavede noget af betydning efter han havde gjort denne opdagelse. En lignende holdning kan man støde på vedrørende den store danske astronom Tycho Brahe; Brahe's videnskabelige bidrag reduceres undertiden til hans model for solsystemet, som så oven i købet ikke regnes for betydningsfuld, da den jo ikke ramte "rigtigt". Sådanne reaktioner kan være udtryk for uvidenhed om naturvidenskabens udvikling, praksis og historiske betingelser gennem tiderne. Videnskabelige resultater (og videnskabsmænds og -kvinders virke) skal ses og vurderes $i$ sammenhæng med den tid de blev fremsat i. Og i det mindste videnskabshistorisk set er vi for længst kommet ud over den tid, hvor naturvidenskab blev reduceret til dens produkter alene, $i$ form af opdagelser og teorier.

$\mathrm{Nu}$ har Dan Charly Christensen begået en mesterlig biografi om Ørsted, der til fulde må rette op på sådanne misforståelser om denne for det meste retskafne mand, hans 
videnskabelige bidrag og hans betydning i romantikkens og guldalderens København. Jeg vil gerne lykønske forfatteren med hans ualmindeligt velskrevne og overdådigt og smukt illustrerede (og billige) bog, der allerede pryder mange danske hjem. Med utilsløret kærlighed til emnet og overlegent indblik og indlevelse i tiden giver Christensen et uovertruffent portræet af $\varnothing$ rsted, dvs. hans liv både privat og videnskabeligt inkl. det omfattende og farverige persongalleri, som Ørsted havde berøring med både i København og ude i Europa, samt alle de steder han færdedes og boede. Dertil kommer alle de emner Ørsted beskæftigede sig med, såsom fysik, kemi, filosofi, teknologi, litteratur, æstetik, kunst og religion, og alle de administrative sager han tog sig af både som mangeårig sekretær i Det Kongelige Danske Videnskabernes Selskab, som professor og rektor ved universitetet og ikke mindst i sin egen husholdning. Jeg vil betegne bogen som et sandt overflødighedshorn i den sammenhæng. Jeg vil endda gå så langt som til at sige, at ingen andre end Dan Charly Christensen er i stand til at skrive et så omfattende værk om Ørsted.

Christensen har hermed formået, som den første, at forene alle Ørsteds sider, videnskabsmanden, universitetslæreren, organisatoren, kunstner-mæcenen, og ikke mindst manden helt privat som far, xgtemand, søn og bror i én, helt i overensstemmelse med Ørsteds egen livsfilosofi og selvopfattelse. Der ligger omfattende arkivstudier bag bogen, som bringer flere nye sider frem om manden. For første gang omtales f.eks. Ørsteds forlovede i hans unge år, Sophie Probsthein. Ud over at sprede oplysning blandt folk med almindelig interesse for videnskabens og Guldalderens historie, vil bogen blive det sted, hvor man som forsker i første omgang vil søge oplysninger om de sider af Ørsted, man ikke selv har nok kendskab til. F.eks. vil undertegnede gøre brug af den, når det gælder Ørsteds forhold til enevælden og den fremvoksende europæiske nationalisme, smædekampagnen mod Grundtvig, det tætte samarbejde mellem de to Ørsted-brødre og meget andet.

Ørsteds videnskabsfilosofi stod helt centralt i hans videnskabelige virke $\mathrm{i}$ alle dets forgreninger. I selvbiografien fra 1828 nævner han "den Naturlærens Philosophie, han selv havde uddannet sig, som Frugten af den Eftertanke, hvortil Tidsalderens stridende philosophiske Systemer, sammenholdte med Erfaringsnaturlæren, havde opfordret ham." I dannelsen af sin videnskabsfilosofi var Ørsted inspireret flere steder fra. Samtidigt forholdt han sig meget kritisk til filosofien i 
sin samtid. Når det gælder forholdet mellem Ørsted og den store skurk i Christensens fortælling, nemlig filosoffen F.W.J. Schelling, brister argumentationen imidlertid. Mens der aldrig har været tvivl om, at Ørsted lod sig påvirke af filosoffen Immanuel Kant, er der blandt Ørstedforskere blevet brugt en del krudt på at diskutere, om Ørsted lod sig inspirere af Schelling eller ej, og dermed om opdagelsen af elektromagnetismen kan sammenkædes med Schellings eller Kants filosofi. Denne ufrugtbare diskussion ønsker Christensen indædt at fortsætte. Ørsted gennemskuede hurtigt Schelling som spekulativ og ikke-empirisk, som det hedder i bogen (s. 1127. Se også note 16 i kap. 10), og Ørsted skulle derfor have vendt Schelling's Naturphilosophie ryggen. Som om Ørsted ikke kunne kende forskel på fysikere og filosoffer! Det var jo ikke nogen hemmelighed, at Schellings ideer var spekulative; som synonym for Naturphilosophie brugte Schelling netop begrebet Spekulative Physik. Et andet sted er forfatterens argument imod, at Ørsted lod sig inspirere af Schelling, at sidstnævntes "mål ikke var naturvidenskabeligt, men filosofisk" (s. 479-480). Men det er jo irrelevant hvad Schellings mål med hans $\mathrm{Na}$ turphilosophie var, for om Ørsted lod sig inspirere af den eller ej.
Man kan drage en parallel til de logiske positivisters projekt i starten af det 20. århundrede. Det var at reformere filosofien, ikke naturvidenskaben. Ikke desto mindre lod mange naturvidenskabsmænd sig inspirere af de logiske positivisters synspunkter.

Det er ikke historikerens opgave at benægte et træk ved en videnskabsmand, selvom man ikke sympatiserer med det, og da slet ikke når man skriver en biografi. $\mathrm{Og}$ er det ikke også lige præcist den anke Christensen har, når han opponerer mod den "positivistiske" konstruktion af Ørsteds intellektuelle udvikling fra spekulativ til eksperimentel og opdelingen af Ørsteds forfatterskab i det videnskabelige og resten, som Christensen finder hos bl.a. Wilhelm Ostwald (1895), Kirstine Meyer (1920) og Léon Rosenfeld (1970) (sidstnævnte groft fejlciteret, s. 20-21). Christensen løber i øvrigt åbne døre ind, når han positionerer sig i forhold til disse forfattere fra en svunden tid, for der er unægteligt skrevet meget om Ørsted siden; velafbalancerede studier, som både anerkender helheden i Ørsteds virke og hans metafysiske overbevisninger. Christensen hævder ikke desto mindre hårdnakket og utallige gange, at Ørsteds videnskabsfilosofi alene udspringer fra Kants metafysik og erkendelsesteori. Ud over en del forklaringsproblemer 
(tag nu bare titlen på Ørsteds filosofiske testamente Aanden i Naturen fra 1849), fortænkt argumentation (som at Ørsted f.eks. må have kendt til Kants posthume værker, selvom han aldrig nævner dem) og en yderst liberal gengivelse og oversættelse af citater (f.eks. Ørsteds brev til John Herschel gengivet s. 1079), mener jeg forfatterens stædighed på dette punkt giver et mindst ligeså ufrugtbart bidrag til forståelsen af Ørsted idehistorisk, som de forældede fremstillinger Christensen opponerer imod. Christensens behandling af emnet giver slet ikke plads til Ørsteds intellektuelle udvikling gennem et langt liv. Dermed kommer Ørsteds metafysiske ideer til at fremstå som helt statiske, hvilket de bestemt ikke var. Som et yderligere resultat heraf kommer Christensens reduktion af stort set alle datidens videnskabelige uoverensstemmelser til i sidste ende alene at handle om en kamp mellem to metafysiske forestillinger om stoffets struktur, nemlig på den ene side den dynamiske jf. Kant, der var udbredt i Tyskland, og den franske korspuskular-teoretiske på den anden side, mest af alt til at fremstå som et unuanceret og forfladiget billede af datidens naturvidenskab.

Desværre er bogen nogle steder ret sløset, f.eks. når det gælder gengivelse og oversættelser af citater, der skal underbygge forfatterens argumentation. I sine referencer er bogen direkte mangelfuld. Flere steder er der hverken referencer til de videnskabelige værker, der omtales, eller historiske studier af de samme værker. Det kan også undre, at der hvor Christensen f.eks. beskriver forholdet mellem Ørsted og hans protegé Ludvig Colding, og spørgsmålet om energisætningen (som Colding var en af de første til at opdage) kan kædes sammen med romantikkens idegrundlag, er der ingen reference til Kenneth L. Canevas grundige analyse af netop det spørgsmål fra 1997. I stedet får vi henvisninger til en gammel tekst fra 1929. Der er faktisk slet ingen referencer til Canevas omfattende studier af Ørsted og tysk romantisk naturvidenskab i litteraturlisten. Man kunne fristes til at tro, at det skyldes at Caneva fortæller en anden historie end Christensens. Men dertil kan fremfores at Christensen har inkluderet de fleste af de af undertegnedes studier, som han gør brug af, også selvom der ikke altid følger en reference med til dem på relevante steder. Det kunne nemt få en til at opfatte forfatteren som noget karrig med at kreditere sine inspirationskilder.

Trods ovennævnte kritikpunkter kan jeg kun opfordre alle til at give sig i kast med den pågældende bog og lade sig transportere men- 
talt tilbage $\mathrm{i}$ tiden for at følge $\varnothing_{\mathrm{r}-}$ steds begivenhedsrige rejse gennem livet og undervejs nyde de smukke billeder.

POUL DUEDAHL

\section{Darwins kamp for overlevelse}

Charles Darwin: Menneskets afstamning ogparringsvalget, oversat af J. P. Jacobsen, bearbejdet af Lotte Langer, introduktion ved Hans Henrik Hjermitslev, Husets Forlag, 2009, 488 sider, 399,- kr.

Darwin-industrien lever i bedste velgående. Hvis nogen overhovedet skulle have været $i$ tvivl, så burde de ikke være det i kølvandet på fejringen af 200-året for Charles Darwins fødsel i det forgangne år. En fejring der selvfølgelig har været fuldt ud berettiget i betragtning af, at hans epokegørende tanker i store træk stadig holder vand; for ikke at tale om hovedværkernes virkningshistorie, der er helt unik for ikkereligiøse skrifter og som kun vanskeligt kan overvurderes.

Men hvad der måske har manglet ind imellem de mange publikationer og fjernsynsudsendelser om Darwins liv og udlægningerne af hans tanker og ideer, er Darwin selv - altså mandens egne ord og dermed selve omdrejningspunktet for de mange fortolkninger. For det er som om Darwin-forskningen har fået sit helt eget liv uden om værkerne; en tendens der næppe vil blive mindre $\mathrm{i}$ årene fremover, $\mathrm{da}$ fortolkningerne jo også har deres helt egen virkningshistorie. Darwin er med andre ord ved at blive udkonkurreret af sin egen succes.

Så meget desto mere befriende er det, at Husets Forlag har påtaget sig opgaven med at give manden selv et talerør med genudgivelsen af hans andet hovedværk, nemlig det om menneskets afstamning og parringsvalget. Ikke af originalen, The Descent of Man, and Selection in Relation to Sex fra 1871, men af J.P. Jacobsens oversættelse fra 1875. Det er faktisk ikke nogen uvæsentlig pointe. Selvom der stadig mangler et indgående studie af, hvor de to værker sprogligt og indholdsmæssigt afviger fra hinanden, så er det ganske givet, at det er Darwins ord gennem netop J.P. Jacobsens stemme, der har sat sig de største spor i dansk åndsliv.

Forlaget og redaktørerne har simpelthen gjort J.P. Jacobsen tilgængelig igen. Ikke blot ved at udgive værket som bog og e-bog, men i lige så høj grad ved igen at gøre værket læseligt. Det vil sige i form af en sproglig bearbejdning af datidens retstavning, der jo for mange nutidsmennesker alene udgør et forstyrrende element. Forsøget på 